\title{
Implementation of Education Quality Improvement in Primary Schools Judging From Teacher Competency Test in Sukabumi Regency
}

\author{
Erni Nurjanah 1a, Esmi Tsalsa Sofiawati ${ }^{1 b}$ \\ ${ }^{1}$ STKIP Bina Mutiara Sukabumi, JI. Pembangunan Salakaso Pasirhalang Sukaraja Sukabumi, West Java Indonesia \\ aerni@unpas.ac.id; b esmi@stkipbms.ac.id \\ *Corresponding Author \\ Whatsapp number: [081318371980]
}

How to Cite: Nurjanah, E., Sofiawati, E., T. (2019). Implementation of Education Quality Improvement in Primary Schools Judging From Teacher Competency Test in Sukabumi Regency. International Journal for Educational and Vocational Studies, 1 (7), 773-776

\section{ARTICLE HISTORY}

Received:11 June 2019

Revised: 6 August 2019

Accepted: 10 October 2019

KEYWORDS

Teacher Competency Test;

Education Quality;

\begin{abstract}
This study aims to understand the extent of the Teacher Competency Test results which include: (a) pedagogical competencies, (b) personality competencies for improving the quality of education in Cilangla State Elementary School, Gandasoli State Elementary School, and Babakan Pamoyanan Elementary School in Sukabumi District. This research uses a qualitative approach that produces descriptive data with case study methods. The results of this study indicate that there are obstacles that occur in the implementation of Teacher Competency Tests, namely the extent of the material being tested, especially in the aspects of pedagogical competence, professional competence and lack of mastery in the operation of the teacher's computer. This is what causes the low scores obtained when implementing the Teacher Competency Test. But on the other hand in improving the quality of education, teachers continue to strive to be able to deliver their students to obtain various achievements in school.
\end{abstract}

\section{INTRODUCTION}

Education is very important in the progress of a nation, therefore education cannot be ignored. Much has been done by the government for the advancement of education, one of which is by efforts to improve the quality of education in schools. This is in line with Law No. 20 of 2003 concerning the National Education System which states that education is a conscious and planned effort to create an atmosphere of learning and learning process so that students actively develop their potential to have religious spiritual strength, self-control, personality, moral intelligence and the skills needed by themselves, society, nation and state (Sisdiknas, 2003).

In addition, the birth of Law No. 14 of 2005 concerning teachers and lecturers who stated that professional teachers and lecturers must have pedagogical competence, personal competence, social competence and professional competence (Republik Indonesia, 2005). Both of these laws are a strong foundation so that teachers have good performance and are able to achieve national education goals as expected and produce generations of students who have various competencies and are able to be competitive -
(Kunter et al., 2013).

For teachers themselves to become professional teachers is not easy, it takes personal effort that is able to develop new ideas and be implemented in improving the quality of education (Girvan, Conneely, \& Tangney, 2016). But in practice in the field this has not been fully able to be implemented properly. Thus, in an effort to improve the quality of education in Indonesia, the government issued a policy through the Teacher Competency Test that must be followed by all PNS and Non-PNS teachers. It dih a rapkan can memetakkan teacher expertise, both pedagogical and professional ongoing basis. Because essentially the quality school or education system depends on the quality of teacher teaching which has an impact on student outcomes (Gore et al., 2017).

In teacher education has a very strategic and irreplaceable role, because teachers are able to interact and communicate with students effectively and teachers can also determine the success of education through improving the quality of education in schools (Arsyad, 2017). 
Education must also be able to equip and prepare students with a variety of attitudes, skills and adequate knowledge in order to become a strong foundation, and make a creative, innovative, productive, and independent person. Therefore we need professional teachers who have various competencies and are ready to devote themselves to the community, nation, and country through education (Mulyasa, 2017).

The civilization of a nation is inevitable, while the progress of a nation depends on the level of education. With good quality education, it will produce quality humans. This revealed the importance of quality education. While quality education itself is inseparable from the results of education, the content of education, the educational process, educational assessment, educational facilities and infrastructure, education funding, education management and more importantly the educators (teachers) and education personnel as providers of education in schools (Sujanto, 2018).

Based on the description that, it is felt necessary to do research with the title "Implementation of the Education Quality Improvement In Primary Schools Seen From Master Competency Test In Sukabumi" to identify the problem as follows:

The issue of education at this time has not been completely well touched, because it still measures academic value as a form of educational success. The teacher is still blamed if the student's cognitive results are disappointing. Therefore it is necessary to improve the quality of education one of them through teacher competency tests.

The low quality of education in Indonesia is blamed because the quality of teachers is still below the standard, starting from the quality of teaching, teaching methods and teaching strategies. So the government is trying to respond to this problem one of them by holding a Teacher Competency Test.

Based on the background of the problem, the researcher proposes the formulation of the problem, How is the pedagogical competence and teacher's personal competence in an effort to improve the quality of education in elementary schools? The purpose of this study is to identify pedagogical competencies and teacher personal competencies in improving the quality of education in Sukabumi District Elementary School.

\section{METHODS}

\subsection{Purpose and Place of Research}

The purpose of this study was to determine the results of the implementation of the Teacher Competency Test in improving the quality of education in primary schools.

This research was conducted in three schools in Sukabumi Regency, namely SDN Cilangla, SDN Gandasoli and SDN Babakan Pamoyanan. This research was conducted for 7 months, from February 2019 to August 2019.

\subsection{Research Methods and Procedures}

In this study, researchers used a qualitative approach to the case study research method. In qualitative research, the data generated descriptively are derived from various behaviors, writing and speech through observations from the surrounding environment that are the subject of research (Guba \& Lincoln, 1981). The data obtained is generated from interviews, observations, and documentation with informants, then the coding is done as a process of data analysis in the presentation of research reports (Vogt, Vogt, Gardner, \& Haeffele, 2014). The informants in this study were the school principal, a number of teachers who had participated in the Teacher Competency Test for both PNS and Non-PNS from three schools namely 19 PNS and 13 Non-PNS. This method facilitates and expedites researchers in making observations. While the researchers themselves become the main instruments that collect data from interviews, observations, and documentation. This is done so that the facts contained in the field can be felt directly.

\section{RESULTS AND DISCUSSION}

Talking about the teacher, according to the Regulation of the Minister of Education National number 16 in 2007 and in the book guide the implementation of the guarantee of quality of education of the standard of education and staff education mentioned that indicators of the availability and competence of teachers that appropriate provisions are teachers who have the competence pedagogic, personable, professional, and social the good. Being a teacher is not easy, let alone having to meet certain quality standards that have been set, teachers are required to be able to develop themselves in accordance with the progress of science and technology (Pendidikan dan Kebudayaan, 2016). While in the context of education itself, quality improvement is seen from various aspects, both input, process and output (Kusnadi, 2017). So with so need the test of competence of teachers and how its implementation in schools in order to manifest the quality of education that is good and there is an increase. Every teacher needs a competence that is good for the present and develop knowledge in real-time in learning to use various kinds of methods and approaches are good in order to produce the quality of education that is good anyway (Nabi \& Ermuhametovna, 2016). One of the efforts to improve kompetensei teachers such, the government organized a Test Competence of Teachers (UKG), which aims to measure the extent to which the competence of teachers both in professional and pedagogic, as well as provide convenience for the government to implement development and coaching profession teachers.

Reflecting on the results of the Competency Test of elementary school teachers in the Regional Education Balance Sheet (NPD) in Sukabumi Regency in 2015 (Sukabumi, 2015), 2016 (Sukabumi, 2016) and 2017 (Sukabumi, 2017). 


\section{PrimarySchool}

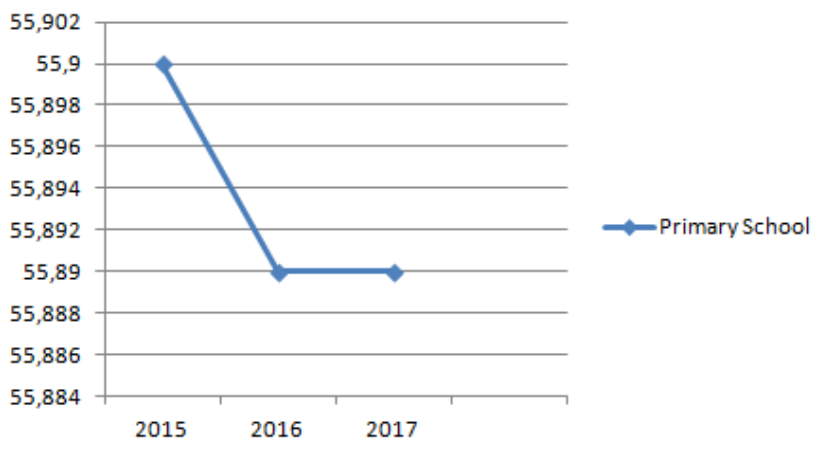

Figure 1. Primary School

Based on the picture above shows that the average results of Competency Test has decreased. In 2015 the average value of the acquisition of Sukabumi district teacher Competency Test 55.9. In 2016 and 2017 the average value of the Teacher Competency Test results was 55.89. While the data obtained from the 2018 Regional Education Balance Sheet, does not show the results of the Teacher Competency Test (Sukabumi, 2018). This happens because the Competency Test itself has not been consistently carried out annually in each region. Likewise for Sukabumi district itself, in 2018 the Teacher Competency Test was not carried out for primary school level including in the three schools studied. This problem occurs because of various things being considered, in addition to each teacher having to pay when they will carry out the Teacher Competency Test, other things also reveal that this Teacher Competency Test has not yet fully met the teacher's competency, because the Competency Test conducted only meets pedagogical or academic competencies. While the increase in $\mathrm{m} \mathrm{u}$ tu education is required other competencies that social competence, personal competence and professional competence. In the field shows that not all teachers who have good Competency Test scores, are also good in implementing in schools in an effort to improve the quality of education due to limitations in operating computers, and vice versa.

The results of the Teacher Competency Test are actually able to fulfill three aspects of quality education. The three aspects are product, effect and impact. The results of the competency test in the form of this product are the form to be achieved from the implementation of the competency test that has been done. The effect of the competency test is changes that occur further after the competency test process is carried out as a whole for teachers who have carried out the competency test. While the impact is the influence that occurs further which is the result of the product and the effect that has an effect on improving the quality of education.

Based on the results of research in three elementary schools, there are findings that refer to pedagogical competencies that must be possessed by teachers. This can be seen in the matrix in table 1.
Table 1. Matrix Pedagogical

\begin{tabular}{ll}
\hline \multicolumn{1}{c}{\begin{tabular}{c}
\multicolumn{1}{c}{ Pedagogical Competency } \\
Aspects
\end{tabular}} & \multicolumn{1}{c}{ Owned Indicators } \\
\hline $\begin{array}{l}\text { Mastering the characteristics of } \\
\text { students }\end{array}$ & $\begin{array}{l}\text { Understanding student characteristics } \\
\text { (background, physical, emotional, moral, } \\
\text { social and intellectual) }\end{array}$ \\
\hline $\begin{array}{l}\text { Mastering the theory and } \\
\text { principles of learning in } \\
\text { educating }\end{array}$ & $\begin{array}{l}\text { Understand and apply learning methods and } \\
\text { strategies in an effort to approach students }\end{array}$ \\
\hline Develop curriculum & $\begin{array}{l}\text { Develop syllabus and lesson plans according } \\
\text { to curriculum }\end{array}$ \\
\hline Develop student potential & $\begin{array}{l}\text { Analyze and identify the potential students } \\
\text { have through school programs in learning }\end{array}$ \\
\hline Communicative & $\begin{array}{l}\text { Able to communicate well with students and } \\
\text { guardians of students }\end{array}$ \\
\hline Evaluation & $\begin{array}{l}\text { Conduct and analyze the process of } \\
\text { evaluating student learning outcomes on an } \\
\text { ongoing basis }\end{array}$ \\
\hline
\end{tabular}

Based on the competency aspects above, everything must be done by the teacher as an educator. This is reinforced by the opinion of Colquitt, Lepine and Wesson who revealed that routine task performance involves well-knowing responses to demands that occur in a normal, routine, or otherwise predictable way. In these cases, employees tend to act more or less habitual or programmed way that is very slow from one instance to another (Colquitt, Lepine, \& Wesson, 2012). Meanwhile, the reality reveals that the three schools studied not all teachers understand and mengimple me ntasikan cognitive aspects of pedagogical overall. $M$ engingat material tested in the Competency Test is too broad, while on the other hand the process selesksi and teacher recruitment only in school base is still loose and less attention to their competence and academic qualifications possessed by each teacher. Lack of understanding of the theory and implementation of teaching and how to effectively teach students according to the education they aspire to, especially when teachers are confronted with the Teacher Competency Test. So in this case the government itself issued the provisions of Government Regulation No. 19 of 2017 concerning teachers (Indonesia, 2017).

Another obstacle faced by teachers in Competency Test is mastery in operating computers, especially for teachers who will be nearing retirement for about 2-4 years. These problems make and affect the small value of the results of the Teacher Competency Test.

Reality in the educational environment states that teacher skills in educating elementary school students are very important compared to the expansion in mastery of teaching materials, teachers must have high creativity in developing student learning techniques. This has been done by the teachers in learning in schools which is the impact of the Competency Test that has been done. So dili hat of the process of improving educational quality of the three schools in meticulous been reflected and able to bear it. Various student achievements were achieved in various activities carried out both between schools at the district and district levels. 
Basically pedagogical competence can be described as the ability and willingness of teachers to regularly apply the attitudes, knowledge and skills of teachers to students according to the correct learning design. Therefore, to realize the quality of education in the learning process, high commitment is needed in order to realize all the aspirations. Whereas in the professional competencies that must be possessed by teachers is to have appropriate academic qualifications, so that the teacher is able to realize national education goals. This is in line with government regulation No. 19 of 2005 article 28 (Pemerintah, 2005) that professional teachers are teachers who are able to master learning material widely and deeply so that the teacher is able to guide students (Mulyasa, 2017).

The awareness of the teachers who individually want to develop their competence, means that the teacher has awakened his internal spirit to continue to change for the better. This awareness sometimes does not develop by itself. Therefore, through the Teacher Competency Test that is carried out is an effort to provide encouragement that together are awakened and want to be awakened from their comfort zones to realize their shared dreams about school and the desired education.

\section{CONCLUSION}

Government efforts in improving the quality of education in Indonesia through the Teacher Competency Test are good, but need to be improved, given the challenges of education are so complex and dynamic. The education world needs teachers who have various competencies to improve the quality itself.

So far there are still many obstacles faced by teachers and become an important issue in improving the quality of education through the Competency Test conducted. Both in terms of financing, academic qualifications and mastery of technology (computers). For that we need cooperation from various parties in realizing the quality of education and the efforts of teachers to continue to want to develop themselves and improve their competencies.

\section{REFERENCES}

Arsyad, A. (2017). Analysis Of Supervisor Competencies In Implementing School Based Management Towards Quality Improvement Of Secondary Schools. Advances in Social Science, Education and Humanities Research, 118, 1022-1028.

Colquitt, J. A., Lepine, J. A., \& Wesson, M. (2012). Organizational Behavior: Improving Performance and Commitment in the Workplace 3rd Edition. McGraw-Hill Education; 3 edition. McGraw-Hill Education. https://doi.org/10.1016/B978-0-12-375000-6.00263-9

Girvan, C., Conneely, C., \& Tangney, B. (2016). Extending Experiential Learning in Teacher Professional Development. Teaching and Teacher Education, 58,
129-139. https://doi.org/10.1016/j.tate.2016.04.009

Gore, J., Lloyd, A., Smith, M., Bowe, J., Ellis, H., \& Lubans, D. (2017). Effects of Professional Development on The Quality of Teaching: Results from a Randomised Controlled Trial of Quality Teaching Rounds. Teaching and Teacher Education, 68, 99-113. https://doi.org/10.1016/j.tate.2017.08.007

Guba, E. G., \& Lincoln, Y. S. (1981). Effective Evaluation-Improving The Usefulness of Evaluation Results Through Responsive and Naturalistic Approaches. Jossey-Bass Publishers. San Fransisco: Jossey-Bass Publishers.

Indonesia, R. Peraturan Pemerintah Republik Indonesia Nomor 19 Tahun 2017 (2017).

Kunter, M., Klusmann, U., Baumert, J., Richter, D., Voss, T., \& Hachfeld, A. (2013). Professional competence of teachers: Effects on instructional quality and student development. Journal of Educational Psychology. https://doi.org/10.1037/a0032583

Kusnadi. (2017). Konsep Dasar dan Strategi Penjaminan Mutu Pendidikan: Sebagai Review Kebijakan Mutu Pendidikan. Indonesian Journal of Education Management \& Administration Review, 1(2).

Mulyasa, E. (2017). Guru Dalam Implementasi Kurikulum 2013. Bandung: Remaja Rosdakarya.

Nabi, Y., \& Ermuhametovna, N. (2016). Education Quality in Kazakhstan in The Context of Competence-Based Approach. Internasional Journal of Environmental and Science Education, 11(10), 3423-3435.

Pemerintah, P. Nomor 19 Tahun 2005 Tentang Standar Nasional Pendidikan (2005).

Pendidikan dan Kebudayaan, M. Nomor 28 Tahun 2016 Tentang Sistem Penjaminan Mutu Pendidikan Dasar dan Menengah, Pub. L. No. 28 (2016).

Republik Indonesia, U.-U. Undang-Undang Republik Indonesia Nomor 14 Tahun 2005 Tentang Guru dan Dosen (2005).

Sisdiknas. Undang-Undang Republik Indonesia Tentang Sistem Pendidikan Nasional, Nomor $20 \S$ (2003).

Sujanto, B. (2018). Pengelolaan Sekolah: Permasalahan dan Solusi. Jakarta: Bumi Aksara.

Sukabumi, K. (2015). Neraca Pendidikan Daerah 2015. Kementrian Pendidikan Dan Kebudayaan.

Sukabumi, K. (2016). Neraca Pendidikan Daerah 2016. Kementrian Pendidikan Dan Kebudayaan.

Sukabumi, K. (2017). Neraca Pendidikan Daerah 2017. Kementrian Pendidikan Dan Kebudayaan.

Sukabumi, K. (2018). Neraca Pendidikan Daerah 2018. Kementrian Pendidikan Dan Kebudayaan.

Vogt, W. P., Vogt, E. R., Gardner, D. C., \& Haeffele, L. M. (2014). Selecting The Right Analyses For Your Data Quantitative, Qualitative, and Mixed Methods. The Guilford Press. 